\title{
MODEL SISTEM PANAS BUMI LAPANGAN KARAHA - TALAGA BODAS BERDASARKAN INVERSI 2D DATA MAGNETOTELLURIK
}

\section{THE KARAHA - TALAGA BODAS GEOTHERMAL SYSTEM MODEL, BASED ON 2D INVERSION OF MAGNETOTELLURIC DATA}

\section{Ilham Arisbaya ${ }^{1}$, Aldinofrizal ${ }^{2}$, Yayat Sudrajat ${ }^{1}$, Eddy Z. Gaffar ${ }^{1}$, Asep Hardja $^{2}$}

${ }^{1}$ Pusat Penelitian Geoteknologi, LIPI, Jl. Sangkuriang Bandung 40135

${ }^{2}$ Program Studi Geofisika Universitas Padjadjaran, Bandung

\begin{abstract}
ABSTRAK Daerah Karaha-Talaga Bodas, yang terletak di kawasan Utara Gunung Galunggung, Tasikmalaya diduga memiliki prospek panas bumi, dengan adanya manifestasi permukaan berupa fumarol dan mata air panas. Metode Magnetotelurik (MT) diaplikasikan untuk mengidentifikasi struktur resistivitas bawah permukaan yang terkait dengan sistem panas bumi. Pengolahan data MT dilakukan melalui beberapa tahap, yaitu transformasi Fourier, seleksi crosspower, analisis rotasi, analisis kontak vertikal dan inversi dengan hasil akhir berupa model sebaran 2D. Hasil pengolahan data menunjukan adanya lapisan konduktif dengan nilai resistivitas 1-10 Ohm.m, yang diduga berperan sebagai lapisan penudung. Zona reservoir berupa daerah dengan nilai resistivitas 10-100 Ohm.m. Nilai resistivitas yang lebih besar dari 100 Ohm.m berkorelasi dengan batuan beku yang biasa dianggap sebagai sumber panas. Interpretasi hasil pengolahan data MT diintegrasikan dengan informasi geologi untuk mendapatkan gambaran sistem Panas Bumi Karaha-Talaga Bodas.
\end{abstract}

Naskah masuk : 16 Agustus 2018

Naskah direvisi : 18 Oktober 2018

Naskah diterima : 19 Oktober 2018

Ilham Arisbaya

Pusat Penelitian Geoteknologi, LIPI

Jl. Sangkuriang Bandung 40135

Email : ilham.arisbaya@lipi.go.id
Kata kunci: Panas Bumi, Karaha-Talaga Bodas, Magnetotelurik, Resistivitas.

ABSTRACT The area of Karaha-Talaga Bodas is estimated to have a geothermal prospect characterized by emerge surface manifestations of fumaroles and hot springs. The Magnetotelluric Method (MT) has been applied to identify the subsurface resistivity structure of the KarahaTalaga Bodas Geothermal Area. Location of Karaha-Talaga Bodas is on the north of Mount Galunggung, Tasikmalaya. The MT data processing performed with: Fourier transform, crossover selection, rotation analysis, vertical contact analysis and inversion with the result of $2 D$ resistivity model. The results of data processing shows an existance conductive layer with a value of 1-10 Ohm.m allegedly acts as a caprock. The reservoir zone with a resistivity value of 10-100 Ohm.m and resistivity value greater than 100 Ohm.m correlates with the basement / hot rock. Interpretation of MT data processing results integrated with geological information to get an overview of the KarahaTalaga Bodas geothermal system.

Keywords: Geothermal, Karaha-Talaga Bodas, Magnetotelluric, Resistivity.

\section{PENDAHULUAN}

Bertambahnya jumlah penduduk dan pertumbuhan ekonomi telah menyebabkan peningkatan kebutuhan akan energi. Jumlah penduduk Indonesia pada tahun 2016 mencapai 258,7 juta jiwa dengan laju pertumbuhan 1,27\% per tahun (BPS, 2017). Sementara konsumsi 
energi listrik total masyarakat Indonesia pada tahun 2017 mencapai 234 TWh dengan proyeksi pertumbuhan kebutuhan sebesar $8,4 \%$ per tahun (RUPTL-PLN, 2017). Salah satu sektor yang sangat diharapkan dalam proyeksi bauran energi di masa mendatang adalah sektor panas bumi. Namun hingga tahun 2016 sektor panas bumi Indonesia baru menyumbang $1,64 \%$ dari total 59.656,3 MW energi listrik yang dibangkitkan (Statistik-Ketenagalistrikan, 2016).

Berdasarkan statistik EBTKE 2016 (StatistikEBTKE, 2016), Jawa Barat merupakan provinsi dengan potensi sumber daya panas bumi terbesar di Indonesia, 18\% dari total potensi 11.998 MW. Bahkan 5 dari 11 pembangkit listrik tenaga panas bumi (PLTP) terpasang di Indonesia pada tahun 2015 berada di Provinsi Jawa Barat, yaitu Kamojang, Gunung Salak, Darajat, Wayang Windu, dan Patuha. Kelima PLTP ini menyumbang $83,06 \%$ produksi listrik panas bumi Indonesia tahun 2015. Jawa Barat juga memiliki 5 (lima) dari 8 (delapan) lapangan panas bumi dengan karakter reservoir dominasi uap di dunia (Raharjo et al., 2016), salah satunya adalah lapangan Karaha-Talaga Bodas.

Lapangan panas bumi Karaha-Talaga Bodas saat ini berada dalam tahap akhir persiapan produksi, dengan potensi sebesar $50 \mathrm{MW}$ (Statistik-EBTKE, 2016). Lapangan panas bumi ini terletak pada suatu punggungan berarah utara-selatan di utara Gunung Galunggung, Jawa Barat. Bagian utara lebih dikenal sebagai daerah Kawah Karaha, sedangkan bagian selatan dikenal sebagai daerah Talaga Bodas. Karaha-Talaga Bodas diyakini memiliki potensi panas bumi besar dengan sistem dominasi uap dan temperatur mencapai $350^{\circ} \mathrm{C}$ (Powell et al., 2001). Penelitian-penelitian sebelumnya (Allis et al., 2000; Allis dan Moore, 2000) mengidentifikasi bagian-bagian sistem panas bumi lapangan Karaha - Talaga Bodas berupa zona permebilitas rendah, zona reservoir dominasi uap di bagian selatan, dan zona reservoir dominasi liquid pada kedalaman yang lebih dalam. Lebih lanjut Moore et al. (2002) menjelaskan bahwa sistem dominasi likuid temperatur tinggi terbentuk sebagai akibat intrusi diorit, sebelum kemudian berubah menjadi dominasi uap.

Model gravity dari Tripp et al. (2002) mengkonfirmasi intrusi vertikal batuan beku di bawah Talaga Bodas serta mengusulkan adanya intrusi konkordan sejauh $10 \mathrm{~km}$ ke arah utara. Sementara itu Raharjo et al. (2002) menggambarkan bahwa temperatur reservoir Karaha-Talaga Bodas menunjukkan variasi dengan temperatur yang semakin meningkat ke arah selatan. Para penulis ini menjelaskan fenomena variasi temperatur dengan pemodelan ke depan dan inversi Magnetotelurik (MT) dalam kerangka satu dimensi (1D), yang memperlihatkan bahwa lapisan penudung (clay cap) menebal ke bagian selatan seiring semakin intensifnya proses alterasi. Sayangnya model MT ini lebih fokus pada geometri clay cap berdasarkan pemodelan 1D sehingga kurang menggambarkan sistem panas buminya secara utuh.

Model sistem panas bumi merupakan salah satu aspek penting yang perlu dipelajari pada tahap eksplorasi. Geometri dari suatu sistem panas bumi biasa dibangun terutama berdasarkan metode geofisika, salah satunya menggunakan metode MT (misal: Maryanto et al., 2017; Singarimbun et al., 2017). Metode ini merupakan salah satu metode utama dalam kegiatan eksplorasi panas bumi, menggunakan sumber medan elektromagnetik (EM) pasif untuk mempelajari distribusi konduktivitas bawah permukaan. Logistik lapangan yang relatif simpel dan solusi matematis yang relatif mudah untuk target multidimensi menjadikan metode MT menarik untuk diaplikasikan dalam banyak penelitian kebumian (Garcia dan Jones, 2002). Kelebihan lain dari metode ini terletak pada sistem pengukurannya yang independen antar stasiun pengukuran. Dengan sistem pengukuran seperti ini, penentuan resolusi spatial yang diharapkan menjadi lebih fleksibel berdasarkan jarak antar stasiun pengukuran. Naskah ini akan membahas distribusi resistivitas bawah permukaan sistem panas bumi Karaha-Talaga Bodas berdasarkan model inversi dua dimensi (2D) data MT.

\section{LOKASI PENELITIAN}

Lapangan panas bumi Karaha-Talaga Bodas terletak di perbatasan wilayah Tasikmalaya dan Garut. Berdasarkan peta geologi regional Lembar Tasikmalaya (Budhitrisna, 1986), bagian utara sistem panas bumi ini merupakan formasi hasil gunungapi tua yang terdiri dari breksi gunungapi, breksi aliran tufa dan lava bersusunan andesit sampai basalt. Batuan ini diduga merupakan hasil erupsi Gunung Sadakeling pada umur Plistosen. 


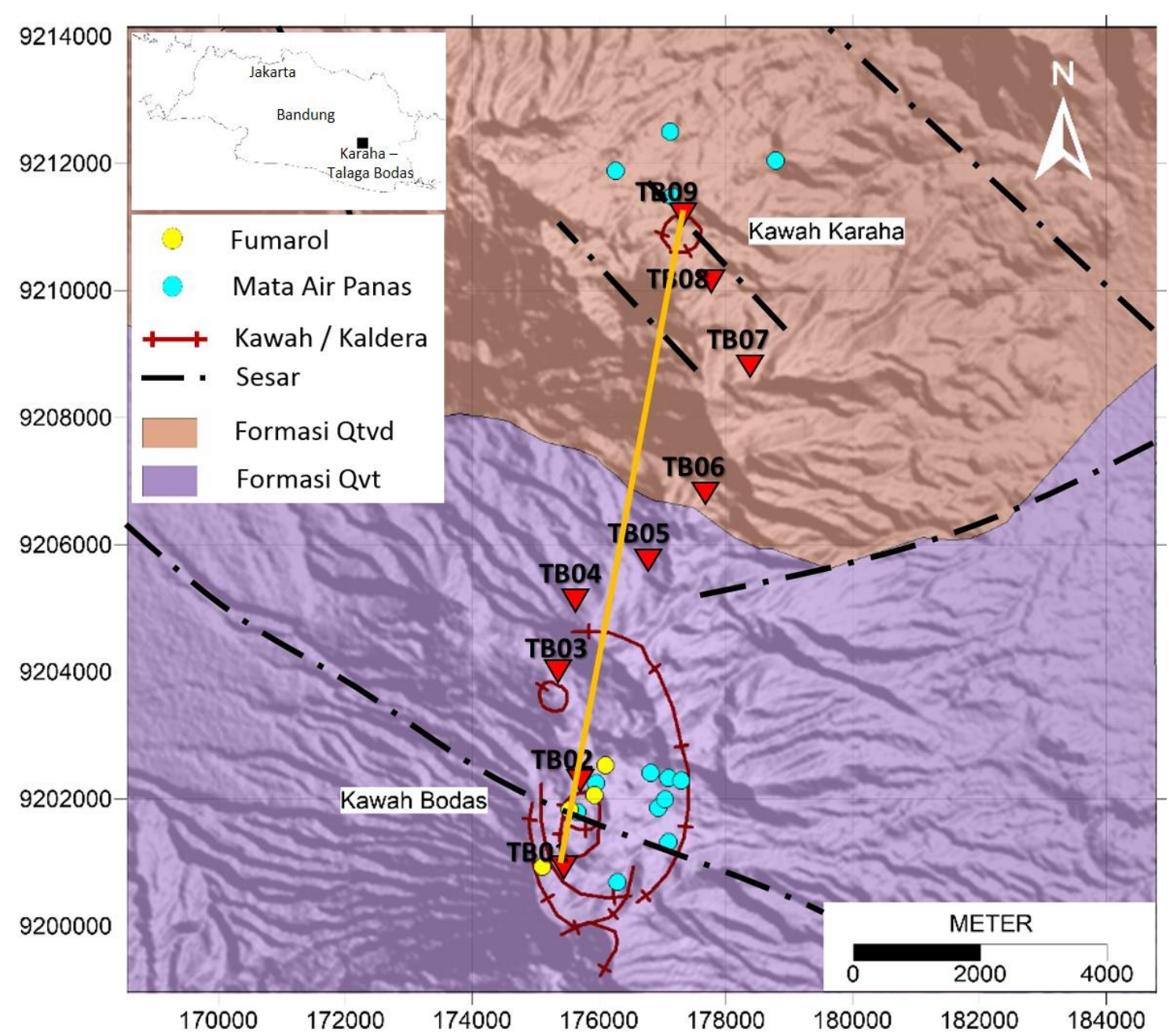

Gambar 1. Peta geologi regional daerah Karaha - Talaga Bodas berdasarkan (Budhitrisna, 1986) dan lokasi manifestasi panas bumi berdasarkan (Raharjo et al., 2002). Segitiga terbalik warna merah merepresentasikan lokasi stasiun pengukuran MT.

Sementara itu bagian selatan merupakan formasi hasil gunungapi muda yang diduga berasal dari Gunung Talagabodas dengan umur Plistosen Akhir hingga Holosen.

Struktur geologi regional Jawa Barat menurut Fauzi et al. (2015) menunjukkan perbedaan arah antara kenampakan di permukaan dengan struktur bawah permukaan berdasarkan peta anomali Bouguer regional. Arah dominan struktur regional permukaan menunjukkan arah N-S dan NNESSW, sedangkan arah dominan struktur bawah permukaan adalah NW-SE dan WNW-ESE. Lapangan panas bumi Karaha-Talaga Bodas berada pada sebuah punggungan yang berarah hampir utara selatan, tegak lurus dengan arah tegasan utama minimum modern (N98E) yang dikemukakan oleh (Nemčok et al., 2001).
Manifestasi permukaan panas bumi yang dijumpai di bagian utara (Karaha) adalah berupa mata air panas. Sementara di bagian selatan (Talaga Bodas) berupa fumarol di Kawah Saat, danau air asam, dan mata air klorida-sulfat-bikarbonat dengan sifat air netral hingga asam. Peningkatan konsentrasi $\mathrm{F}^{-}, \mathrm{Cl}^{-}$, dan $\mathrm{SO}_{4}{ }^{2-}$ pada air danau mengindikasikan bahwa fluida di area ini dipengaruhi oleh gas magmatik (Nemčok et al., 2007).

Data gayaberat di kawasan Karaha-Talaga Bodas menunjukkan nilai anomali tinggi yang memanjang dari Talaga Bodas ke Kawah Karaha. Anomali ini kemudian bertambah tinggi di bagian selatan dan membentuk pola simetris radial. (Tripp et al., 2002) memodelkan pola-pola anomali ini ke dalam dua geometri. Geometri 
pertama adalah intrusi vertikal yang mencapai kedalaman relatif dangkal $(<3 \mathrm{~km})$ di bawah Talaga Bodas. Geometri kedua adalah intrusi konkordan yang meluas sampai kurang lebih 10 $\mathrm{km}$ ke arah utara pada kedalaman $2400 \mathrm{~m}$. Intrusi ini dimodelkan sebagai diorit yang diduga merupakan sumber panas untuk sistem panas bumi Karaha-Talaga Bodas

Sistem panas bumi Karaha-Talaga Bodas terdiri dari 3 (tiga) zona dari atas ke bawah (Moore et al., 2002). Zona pertama adalah batuan penudung dengan ketebalan beberapa ratus $\mathrm{m}$ hingga 1.600 $\mathrm{m}$. Zona ini ditandai gradien suhu konduktif dan permeabilitas yang rendah. Zona kedua merupakan reservoir yang didominasi oleh uap berada di bawah batuan penudung. Zona ketiga merupakan reservoir dominasi likuid berada di bawah zona kedua.

Lebih lanjut Moore et al. (2002) menjelaskan bahwa berdasarkan studi petrografi dan inklusi fluida dari beberapa sampel bor, sistem dominasi likuid temperatur tinggi terbentuk sebelum kemudian berubah menjadi dominasi uap. Sistem dominasi likuid mungkin terbentuk sebagai akibat intrusi diorit yang menerobos hingga kedalaman $<3 \mathrm{~km}$ di dekat Telaga Bodas. Sementara transisi dari sistem dominasi likuid temperatur tinggi ke kondisi dominasi uap dihipotesiskan berhubungan dengan kejadian longsor besar yang terjadi pada Gunung Galunggung sekitar 4200 tahun yang lalu (Moore et al., 2002), seperti dideskripsikan oleh Sudradjat dan Tilling (1984) dan Bronto (1989).

\section{METODE}

Dalam penelitian ini digunakan data MT untuk mencitrakan struktur bawah permukaan lapangan panas bumi Karaha - Talaga Bodas. Metoda MT merupakan salah satu metoda geofisika pasif yang memanfaatkan variasi temporal medan EM alam. Data time series ini kemudian ditransformasikan ke dalam domain frekuensi yang mewakili kontrol kedalaman.

Metode MT pada dasarnya mengukur fluktuasi medan magnet dan medan listrik alami di permukaan bumi pada frekuensi tertentu. Medan listrik alami (Ex dan Ey) diukur dengan dua pasang porous pot, dengan arah utara - selatan (sumbu X), dan barat - timur (sumbu Y). Setiap porous pot berpori ditempatkan di dalam lubang dengan kedalaman $30 \mathrm{~cm}$, dengan jarak ke unit utama adalah $40 \mathrm{~m}$. Kontak resistensi antara porous pot dan tanah dijaga sehingga bernilai kurang dari $1000 \mathrm{~m} \Omega$. Pada saat yang sama, medan magnet alami diukur dengan tiga koil induksi (Hx, Hy, dan Hz). Koil induksi ini dikubur sedalam $50 \mathrm{~cm}$, dan dalam jarak $30 \mathrm{~m}$ dari unit utama. Pengukuran medan magnet dan medan elektrik dilakukan secara bersamaan, terkoordinasi melalui sistem waktu universal GPS.

Pengukuran MT di lapangan panas bumi Karaha Talaga Bodas dilakukan pada Mei 2016. Sebanyak 9 stasiun pengukuran membentuk arah hampir utara - selatan $(\mathrm{N}-\mathrm{S})$ dengan jarak antara stasiun sekitar 1000 meter menyesuaikan kondisi lapangan. Menggunakan instrumen Phoenix MTU5a dengan durasi sekitar 12 jam untuk setiap stasiun pengukuran. Stasiun TB1 berada di ujung selatan, di sekitar Talaga Bodas, sementara stasiun TRB09 berada di ujung utara, di sekitar Kawah Karaha.

Pengolahan data lapangan dilakukan menggunakan SSMT200 dan MT-Editor dari Phoenix Geophysics (2005). Pengolahan data awal terdiri dari kalibrasi, transformasi data dari domain waktu ke domain frekuensi, robust processing, dan pemilihan cross-power. MTeditor memungkinkan untuk melakukan pengeditan cross-power secara grafis untuk mengevaluasi tingkat koherensi impedansi, fase, dan resistivitas semu. Impedansi (Z) dihitung dari data medan magnet $(\mathrm{H})$ dan medan listrik $(\mathrm{E})$ menggunakan persamaan 1 .

$$
Z(\omega)=E(\omega) / H(\omega)
$$

dengan $\omega$ adalah frekuensi sudut. Tensor Impedansi (Z) didefinisikan sebagai rasio antara komponen horizontal medan listrik dan medan magnet yang saling tegak lurus. Tensor impedansi adalah bilangan kompleks yang mengandung informasi tentang resistivitas bumi pada lokasi tertentu sebagai fungsi frekuensi. Resistivitas semu ( $\rho$ ) dihitung untuk setiap elemen tensor impedansi pada setiap frekuensi.

Struktur resistivitas bawah permukaan sistem panas bumi Karaha-Talaga Bodas dalam penelitian ini didekati menggunakan model 2D MT. Dalam model bumi dua dimensi (2D), konduktivitas bervariasi terhadap kedalaman dan satu arah horizontal. Dapat dikatakan bahwa 
resistivitas merupakan fungsi dari $\mathrm{Z}$ (kedalaman) dan Y (horizontal), dan invarian terhadap arah X. Arah invarian resistivitas ini kemudian disebut sebagai arah strike geoelektrik regional. Mode pengukuran untuk kasus bumi 2D terbagi menjadi dua yaitu, Transverse Electric (TE) dan Transverse Magnetic (TM). Dalam kondisi ideal bumi 2D, komponen diagonal tensor impedansi akan bernilai 0 . Namun pada kenyataannya hal tersebut sangat jarang ditemukan, karena adanya efek distorsi atau anomali tiga dimensi (3D).

Dalam penelitian ini, strike geoelektrik regional ditentukan dengan menggunakan metode yang dikemukakan Swift (Swift, 1967). Penentuan strike regional menggunakan metode ini mengimplikasikan adanya ambiguitas sebesar $+90^{\circ}$. Dengan kata lain, kita akan mendapatkan dua nilai sudut ( $\alpha$ dan $\alpha+90)$ tanpa dapat menentukan yang mana yang merupakan strike regional. Terdapat beberapa metode alternatif yang dapat digunakan dalam penentuan strike geolektrik regional. Metode yang banyak digunakan adalah induction vector atau biasa disebut "tipper" yang tidak mengimplikasikan ambiguitas..

Simpson \& Bahr (2005) menjelaskan induction vector (IV) sebagai sebuah vektor bilangan kompleks dari rasio nilai medan magnet arah vertikal $(\mathrm{Hz})$ dengan dan masing-masing nilai medan magnet horisontal ( $\mathrm{Hx}$ dan $\mathrm{Hy}$ ). Komponen real dari $I V$ akan tegak lurus arah strike dalam asumsi bumi 2D dengan magnitudo yang sebanding dengan besarnya gradien konduktivitas atau diskontinuitas (Simpson dan Bahr, 2005; Wiese, 1962). Dengan demikian metode ini dapat digunakan untuk menyelesaikan masalah ambiguitas 90o. Terdapat dua konvensi yang biasa digunakan dalam menampilkan $I V$, yaitu konvensi Parkinson (Parkinson, 1959) dan konvensi Wiese (Wiese, 1962). IV akan menuju konsentrasi arus atau zona konduktif pada konvensi Parkinson, sedangkan pada konvensi Wiese vektor akan menjauh dari konsentrasi arus.

Interpretasi struktur geologi juga dilakukan dengan menggunakan analisis kontak vertikal (Simpson dan Bahr, 2005) dan informasi geologi yang ada. Medan listrik arah Y pada mode TM akan diskontinyu jika melewati kontak vertikal, dengan demikian impedansi dan resistivitas semu pada mode TM akan memperlihatkan pola diskontinyu. Pada mode TE, resistivitas semu cenderung berubah secara halus ketika melewati kontak vertikal.

Pemodelan inversi 2D data MT dilakukan oleh WinGLink (Geosystem, 2008). Perangkat lunak ini menggunakan algoritma nonlinear conjugate gradient (NLCG) dari Rodi dan Mackie (2001). Dalam algoritma ini, trade-off antara kekasaran model dan RMS-misfit diatur melalui parameter regularisasi $\tau$ (tau). Nilai tau besar akan menghasilkan model yang lebih halus dengan misfit yang besar, sementara nilai tau kecil akan menghasilkan model yang lebih kasar dengan misfit yang kecil. Penentuan nilai tau terbaik dilakukan dengan plot curva-L (Hansen, 1992) antara nilai kekasaran terhadap RMS-misfit untuk beberapa nilai tau tertentu. Pemodelan 2D MT dalam penelitian ini menggunakan nilai 3 sebagai parameter regularisasi. Pemodelan inversi dilakukan dengan model awal uniform half-space dengan nilai resistivitas $100 \Omega \mathrm{m}$ dan error floor sebesar 5\%. Rentang frekuensi yang digunakan adalah $0.001-320 \mathrm{~Hz}$ dengan sampling 5 titik setiap dekadenya. Ukuran grid mesh model menggunakan lebar sekitar $250 \mathrm{~m}$.

\section{HASIL DAN PEMBAHASAN}

Proses cross-power dilakukan untuk meningkatkan kualitas data, sehingga diperoleh nilai koherensi data yang lebih baik dari data awal. Nilai koherensi rata-rata data setiap stasiun pengukuran mengalami peningkatan hingga mencapai lebih besar dari $70 \%$, kecuali pada stasiun TB06. Proses akuisisi data pada stasiun ini mengalami masalah pada koil induksi $\mathrm{Hx}$, sehingga data menjadi tidak relevan. Hal ini menyebabkan nilai koherensi data yang rendah. Namun pola kurva resistivitas semu dan fase masih dapat teramati, sehingga diputuskan untuk melakukan smoothing manual tanpa seleksi crosspower. Secara kesuluruhan nilai koherensi rata-rata data bernilai lebih besar dari $70 \%$ kecuali pada stasiun TB06, sehingga dapat dikatakan kualitas data yang digunakan dalam penelitian ini cukup baik.

\section{Strike Regional}

Swift (1967) menyatakan bahwa struktur konduktivitas suatu medium dapat diasumsikan 2D jika konduktivitas konstan dalam satu arah horizontal. Dalam hal ini, digunakan konvensi bahwa konduktivitas berubah dalam sumbu Y, 

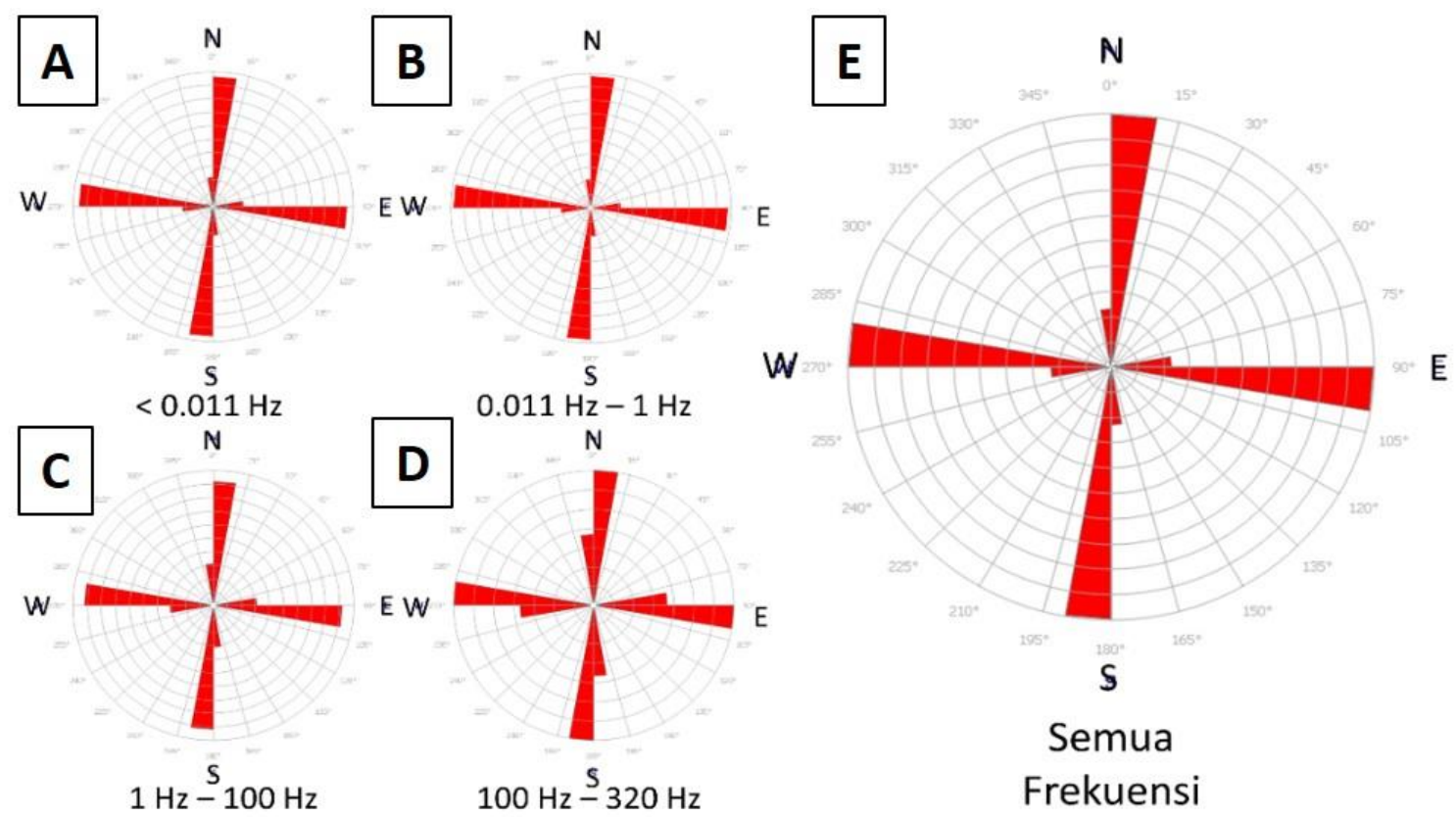

Gambar 2. Diagram Rose nilai sudut medan geoelectrical strike regional berdasarkan metode Swift (Swift, 1967) untuk rentang frekuensi $<0.011 \mathrm{~Hz}$ (A), 0.011-1 Hz (B), 1-100 Hz (C), 100-320 Hz (D), dan untuk semua rentang frekuensi (E).

tetapi konstan dalam sumbu X. Dalam prakteknya, pengukuran MT di lapangan biasanya dilakukan berdasarkan orientasi geografis. Oleh karena itu, tensor impedansi harus diputar ke arah strike geoelektrik regional (Zstrike), sehingga dapat diasumsikan sebagai dua dimensi (Jones dan Groom, 1993; Vozoff, 1991).

Hasil perhitungan sudut skew dengan menggunakan persamaan Swift (Swift, 1967) memperlihatkan sudut strike regional yang berkisar di sekitar $0^{\circ}$. Gambar 2 memperlihatkan diagram rose dari sudut skew pada beberapa interval frekuensi berbeda dan pada seluruh rentang frekuensi. Nilai sudut yang ditampilkan merupakan hasil perhitungan dari semua titik pengukuran, kecuali titik TB06. Besar sudut strike yang didapat dari setiap rentang frekuensi menghasilkan nilai yang tidak jauh berbeda, sehingga dapat diinterpretasikan arah strike pada lokasi penelitian seragam untuk seluruh frekuensi. Namun estimasi nilai strike ini masih mengimplikasikan ambiguitas sebesar $90^{\circ}$, atau dengan kata lain kita mendapatkan dua arah NOE dan N90E.

Untuk mengatasi ambiguitas strike regional, validasi dilakukan menggunakan Induction Vector (IV) atau Tipper. Pada penelitian ini digunakan konvensi Parkinson (Parkinson, 1959), yaitu IV akan mengarah pada bidang konduktif, dan akan tegak lurus dengan arah strike bidang konduktif tersebut pada kasus model bumi 2D (Simpson dan Bahr, 2005; Wiese, 1962). Gambar 3 memperlihatkan plot IV untuk semua stasiun pada seluruh frekuensi.

Terlihat bahwa IV cenderung memiliki pola arah utara - selatan (kotak merah). Pada beberapa frekuensi rendah teramati IV yang arahnya yang tidak menentu (kotak biru), hal ini diduga dipengaruhi noise dan struktur geologi yang kompleks. Misal pada stasiun TB02, arah IV tidak memperlihatkan pola tertentu. Hal ini diduga karena titik pengukuran TB02 berada tepat di Kaldera Talaga Bodas. IV pada titik TB07, TB08 dan TB09 cenderung mengarah ke posisi kelurusan yang melewati daerah sekitar titik TB09. Data pada stasiun TB06 tidak digunakan dalam analisis IV karena kondisi koil Hx yang mengalami gangguan ketika proses akuisisi data. Berdasarkan analisis strike menggunakan persamaan Swift (Swift, 1967) dan Induction Vector dapat disimpulkan arah strike regional pada daerah penelitian yaitu sebesar $90^{\circ}$, selaras dengan arah tegasan utama minimum modern menurut Nemčok et al., (2001).

Rotasi dilakukan pada seluruh data stasiun pengukuran. Proses rotasi sebesar $90^{\circ}$ tidak 


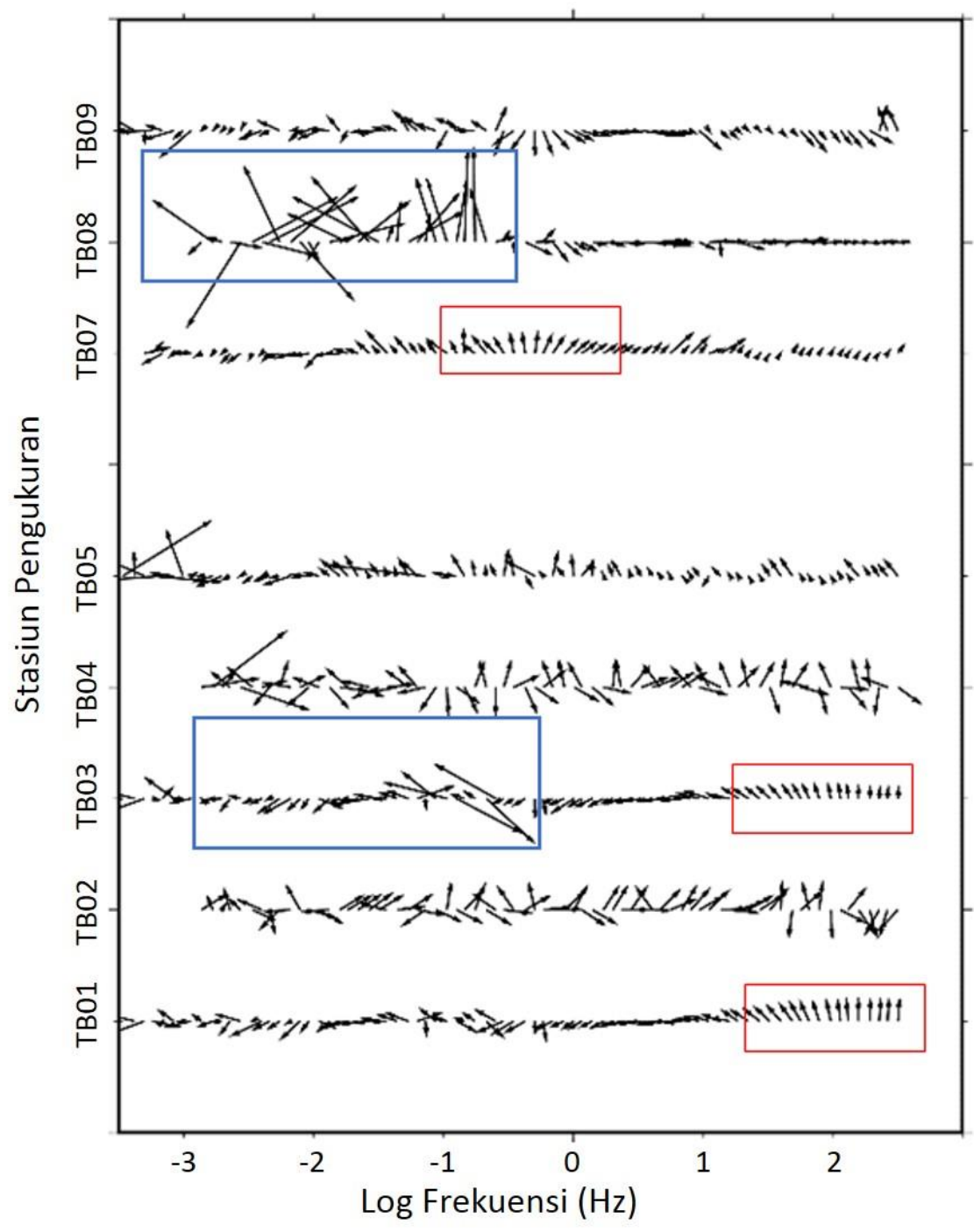

Gambar 3. Induction Vector data MT untuk semua stasiun pengukuran (TB01-TB09, kecuali TB06) pada seluruh frekuensi, pola teratur yang teramati memperlihatkan kecenderungan arah utara -

selatan.

terlihat signifikan pada kurva resistivitas semu dan fase, dan hanya membalikan nilai pengukuran TE dan TM. Terlebih jika proses inversi 2D digunakan data invariant, rotasi sebesar $90^{\circ}$ tidak mempelihatkan perbedaan signifikan. Namun proses rotasi ini akan terkonfirmasi ketika melakukan analisis kontak vertikal dan analisis kualitatif pada pseudo-section mode TE dan TM. Cuplikan beberapa kurva resistivitas semu dapat dilihat pada Gambar 4.

Kurva resistivitas semu pada semua stasiun pengukuran memperlihatkan pola yang hampir sama, yaitu menurun pada frekuensi tinggi dan kemudian kembali meningkat pada frekuensi rendah. Pola ini merupakan pola tipikal pada survei MT di lapangan panas bumi, yang mengindikasikan bahwa gelombang EM melewati lapisan konduktif (Saputra dan Widodo, 2017). Pada Gambar 4 terlihat bahwa sebagian besar kurva resistivitas semu mengindikasikan adanya gangguan di sekitar frekuensi $0,1 \mathrm{~Hz}$. Rentang frekuensi ini dikenal sebagai dead band pada metode MT/AMT (Zhang et al., 2015), dan sering kali memperlihatkan kualitas data yang kurang baik atau terganggu (Garcia dan Jones, 2002). Namun setelah proses cross-power, data memperlihatkan pola yang dapat dikenali walaupun tidak sehalus pada rentang frekuensi lebih tinggi. Oleh karena itu data pada rentang frekuensi sekitar $0,1 \mathrm{~Hz}$ tetap disertakan dalam pemodelan. 

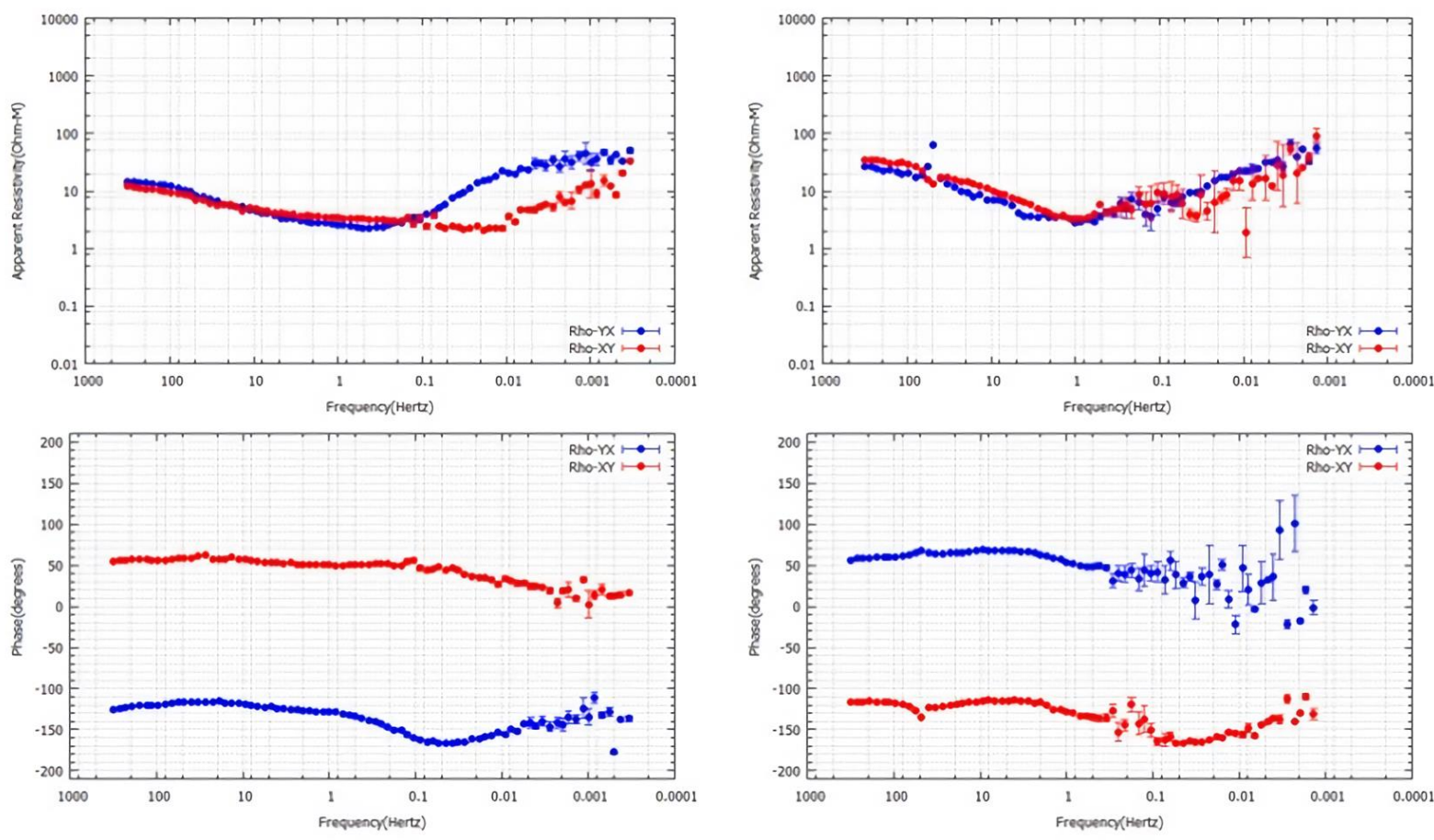

TB1

TB4
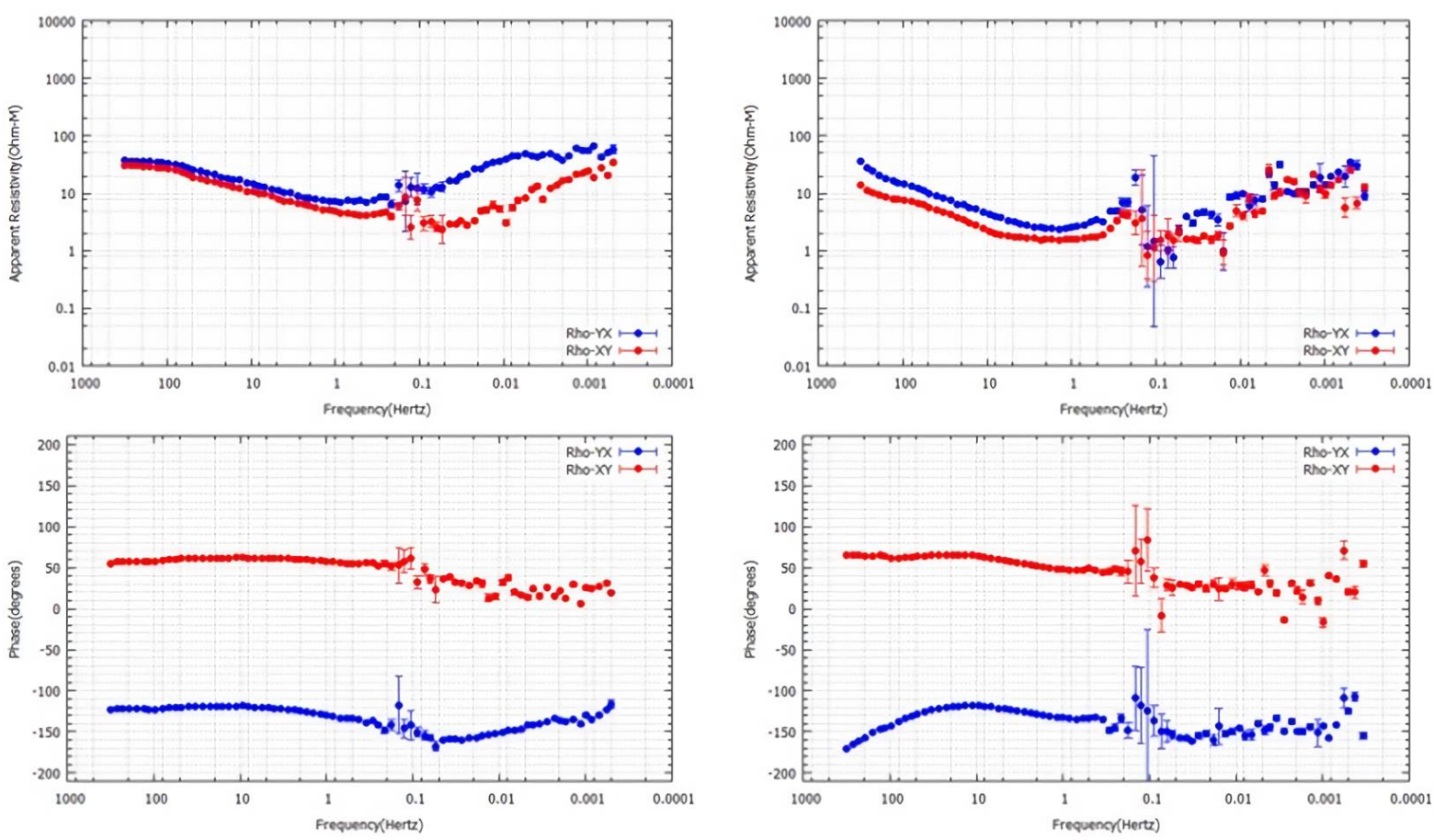

TB7

TB9

Gambar 4. Kurva resistivitas semu pada beberapa stasiun pengukuran (TB01, TB04, TB07, dan TB09), kurva warna merah dan biru merupakan resistivitas semu dalam mode TE dan TM. 

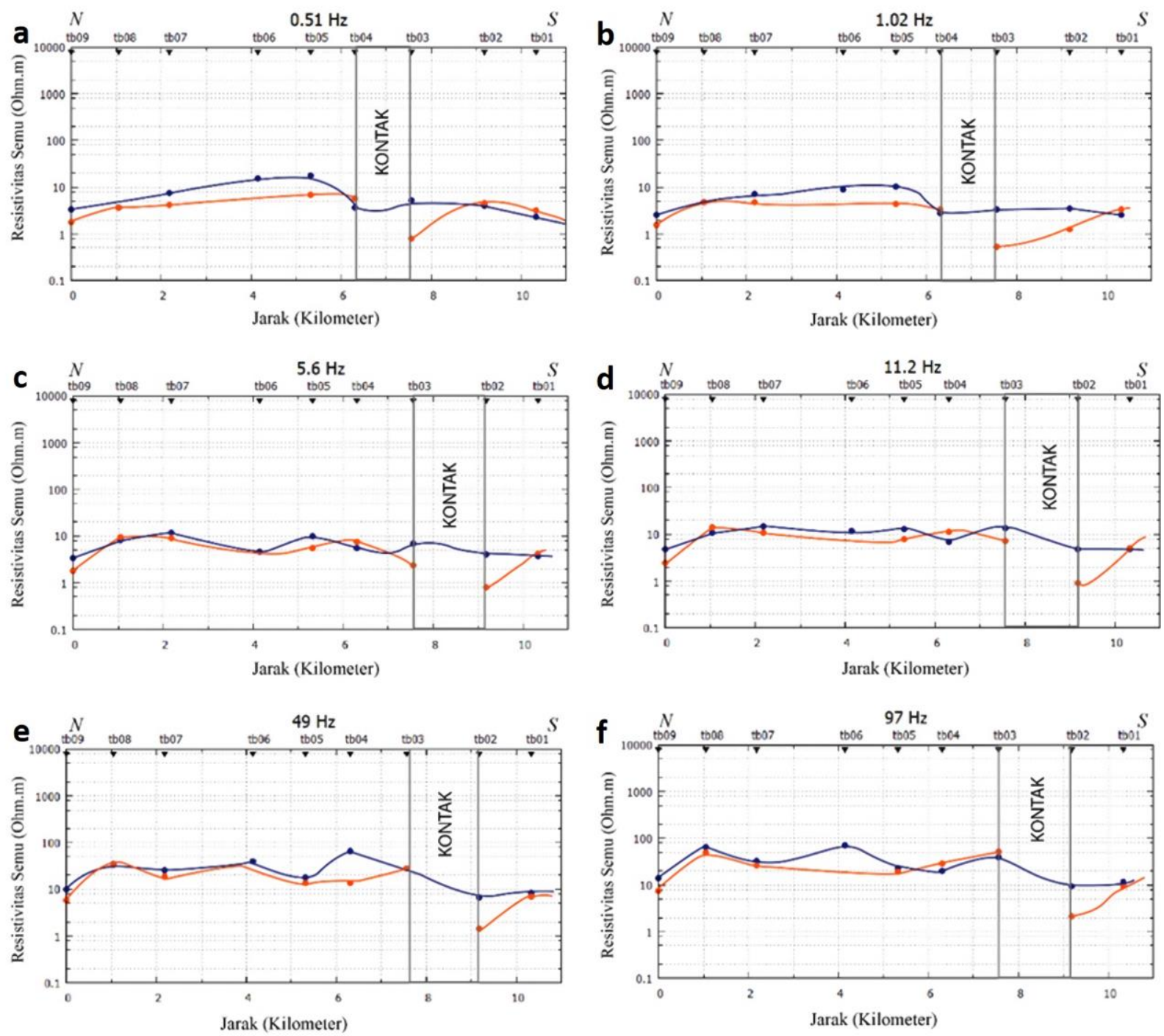

Gambar 5. Kurva analisis kontak vertikal frekuensi tertentu, garis dan lingkaran berwarna jingga adalah resistivitas semu dalam mode TM, sedangkan garis dan lingkaran berwarna biru merupakan mode TE. Pada frekuensi rendah $(0,51 \mathrm{~Hz}$ dan $1,02 \mathrm{~Hz} /$ indeks a dan b), resistivitas semu mode TM memperlihatkan pola diskontinyu di antara stasiun TB03 dan TB04. Sementara pada frekuensi menengah (5,6 Hz dan $11,2 \mathrm{~Hz} /$ indeks c dan d) dan frekuensi tinggi (49 Hz dan $97 \mathrm{~Hz}$ / indeks e dan f), diskontinuitas resistivitas semu mode TM teramati di antara stasiun TB02 dan TB03.

\section{Kontak Vertikal}

Gambar 5 memperlihatkan analisis kontak konduktivitas dengan geometri vertikal seperti patahan atau kontak litologi dengan perbedaan resistivitas cukup besar. Analisis ini dapat dilakukan dengan melihat pola kurva resistivitas TE dan TM pada frekuensi tertentu pada setiap stasiun pengukuran (Simpson dan Bahr, 2005). Frekuensi yang digunakan dalam analisis ini adalah $0,51 \mathrm{~Hz}, 1,02 \mathrm{~Hz}$ (frekuensi rendah), 5,6 $\mathrm{Hz}, 11,2 \mathrm{~Hz}$ (frekuensi menengah), $49 \mathrm{~Hz}$, dan 97
$\mathrm{Hz}$ (frekuensi tinggi). Pemilihan frekuensi tersebut dianggap cukup mewakili seluruh rentang frekuensi data. Pada frekuensi di bawah $0,5 \mathrm{~Hz}$, analisis kontak vertikal tidak dilakukan karena data pada rentang frekuensi tersebut cenderung memiliki nilai koherensi yang kurang baik. Garis dan lingkaran berwarna jingga menunjukan mode TM, sedangkan garis dan lingkaran berwarna biru menunjukan mode TE. Garis hitam vertikal memperlihatkan indikasi adanya kontak vertikal yang dapat diinterpretasikan sebagai patahan. 
Gambar 5 (c, d, e, f) memperlihatkan adanya kontak di antara titik TB02 dan TB03 pada frekuensi tinggi ( $49 \mathrm{~Hz}$ dan $97 \mathrm{~Hz}$ ) dan menengah $(5,6 \mathrm{~Hz}$ dan $11,2 \mathrm{~Hz})$, sehingga fitur terduga kontak vertikal tersebut kemungkinan berada pada kedalaman yang cukup dangkal. Kontak tersebut mungkin merupakan sebuah patahan dangkal yang berkolerasi dengan pola kelurusan yang melewati wilayah di sekitar titik TB02. Manifestasi permukaan panas bumi berupa fumarol dan mata air panas yang ditemukan di sekitar TB02 diduga kuat merupakan hasil dari aktivitas hidrotermal yang naik ke permukaan melewati patahan di antara titik TB02 dan TB03.

Sementara Gambar 5(a, b) menunjukkan bahwa pada frekuensi rendah $(1,02 \mathrm{~Hz}$ dan $0,51 \mathrm{~Hz})$, diskontinuitas teramati di antara stasiun TB03 dan TB04. Nilai frekuensi rendah ini mengindikasikan bahwa kontak vertikal berada pada kedalaman yang lebih dalam. Dengan demikian, terdapat perbedaan posisi dugaan keberadaan patahan antara frekueunsi tinggi dan menengah jika dibandingkan dengan frekuensi rendah. Secara sederhana dapat dikatakan bahwa kontak vertikal pada kedalaman dekat permukaan berada lebih ke selatan dan bergeser ke arah utara seiring bertambahnya kedalaman, atau dugaan patahan memiliki geometri kemiringan ke utara.

\section{Inversi $2 d \mathrm{Mt}$}

Gambar 6 menampilkan plot nilai roughness terhadap RMS misfit untuk beberapa nilai tau.
Parameter tau merupakan parameter yang menjelaskan hubungan nilai RMS misfit dengan roughness pada hasil inversi. Dalam penelitian dilakukan plot nilai roughness terhadap $R M S$ misfit pada beberapa nilai tau, sampai terbentuk kurva tau berbentuk 'L'. Pada penelitian ini dipilih nilai tau yang menghasilkan kombinasi nilai $R M S$ misfit dan roughness terendah. Nilai tersebut diharapkan menghasilkan inversi dengan error rendah, artinya hasil inversi tidak malampaui jauh dari data yang ada dan roughness yang rendah, sehingga model hasil inversi relatif tidak terlalu kasar. Dalam penelitian digunakan nilai parameter tau sebesar 2 .

Pseudo-section resistivitas semu dan fase dapat digunakan untuk menganalisis hasil pemodelan (inversi) dan kecocokannya dengan data hasil pengamatan. Ketika hasil pemodelan memperlihatkan pola yang sama dengan data hasil pengamatan, dapat dikatakan bahwa model yang dihasilkan menunjukkan kesesuaian dengan data hasil pengamatan. Gambar 7 memperlihatkan pseudo-section resistivitas semu (atas) dan fase (bawah) untuk mode TE dan mode TM. Gambar pada bagian kiri menunjukan pseudosection data pengamatan (observed) dan gambar pada bagian kanan menunjukan pseudosection hasil perhitungan (calculated).

Perbedaan penampang resistivitas semu dan fase dapat diamati pada stasiun TB02, TB03 dan zona di antara stasiun TB06 dan TB07 untuk mode TM.

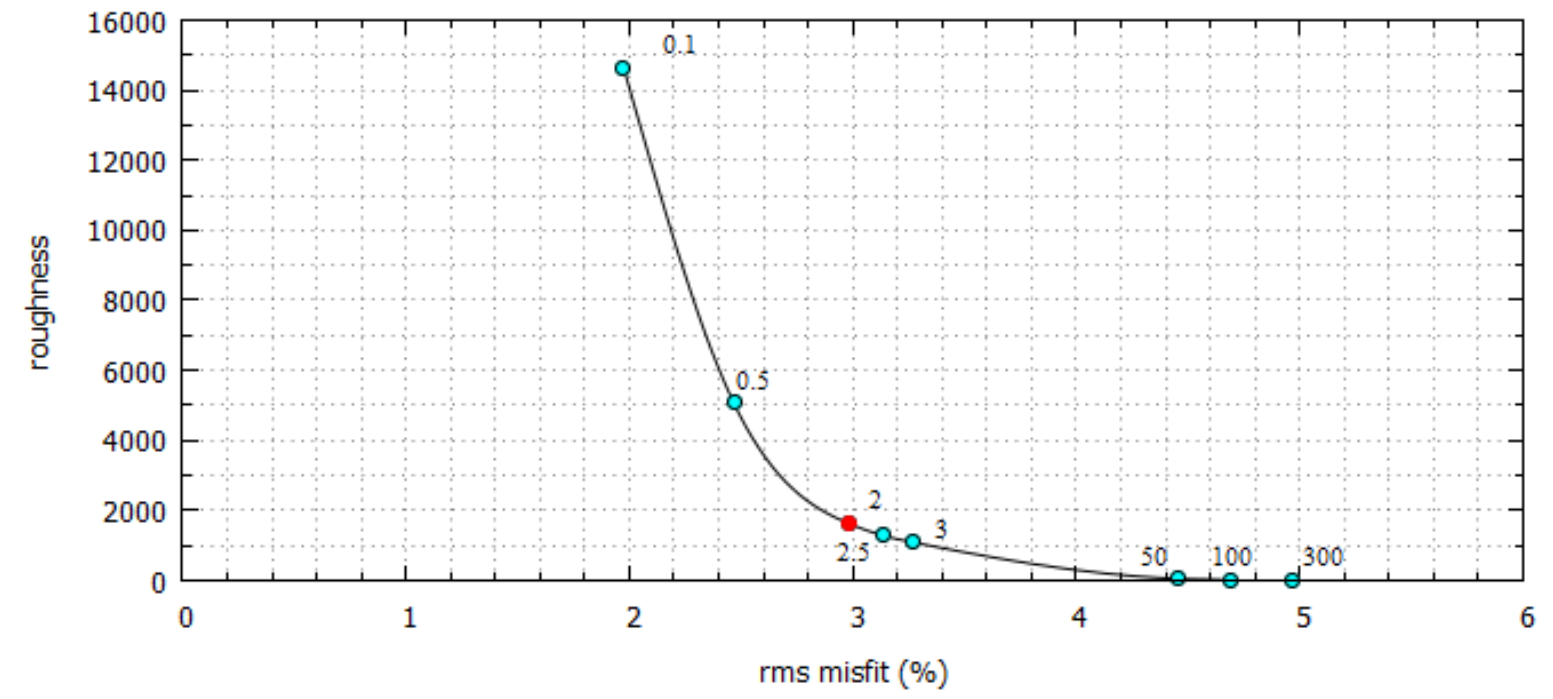

Gambar 6. Plot parameter regularisasi $\sigma(\operatorname{tau})$ yang merupakan kompromi keseimbangan antara komponen roughness dan RMS misfit. 

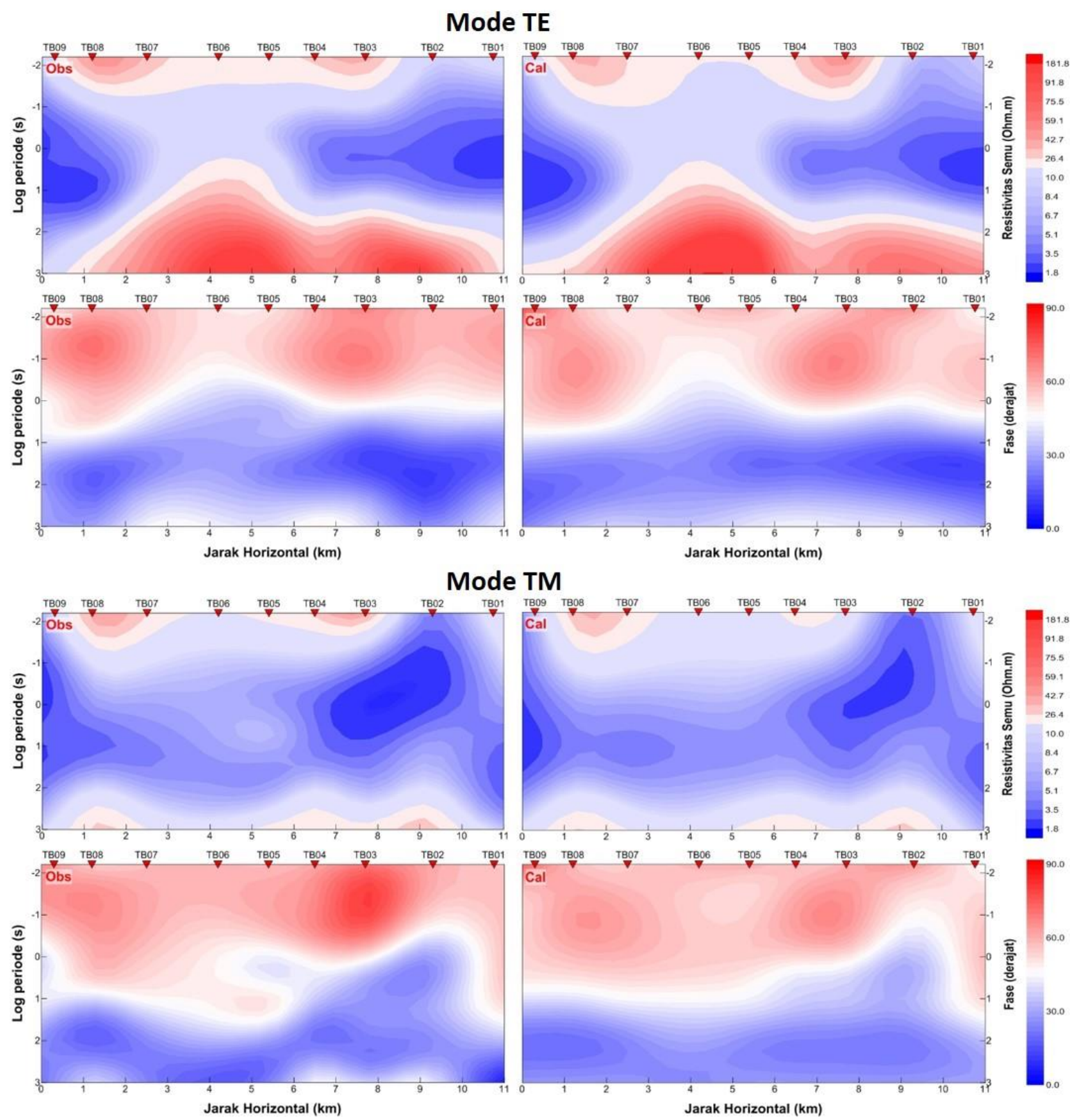

Gambar 7. Perbandingan pseudo-section resistivitas semu dan fase hasil pengukuran di lapangan (Obs) dan hasil respon model (Cal) untuk mode TE (atas) dan mode TM (bawah).

Hal ini dapat disebabkan perubahan data pengamatan yang sangat drastis dan proses pemodelan inversi yang dilakukan tidak mampu untuk memodelkannya. Namun secara keseluruhan data hasil pemodelan menghasilkan pseudo-section dengan pola dan rentang nilai yang hampir sama, baik untuk data mode TE maupun data mode TM.

Penampang resistivitas 2D merupakan hasil dari proses inversi menggunakan parameter yang telah dijelaskan pada sub-bab sebelumnya. Gambar 8 menunjukan penampang resistivitas $2 \mathrm{D}$ wilayah Karaha-Talaga Bodas. Rentang nilai resistivitas yang digunakan untuk menganalisis hasil pemodelan adalah 4 - 3000 Ohm.m. Rentang tersebut cukup menggambarkan variasi resistivitas yang mungkin muncul dalam sistem Panas Bumi. Dalam proses inversi dilakukan iterasi sebanyak 270 kali dan diperoleh nilai RMS misfit sebesar 2,6. Nilai RMS misfit ini menghasilkan respon model yang cukup mendekati nilai data pengamatan, baik resistivitas semu maupun fasenya seperti terlihat pada Gambar 7. 


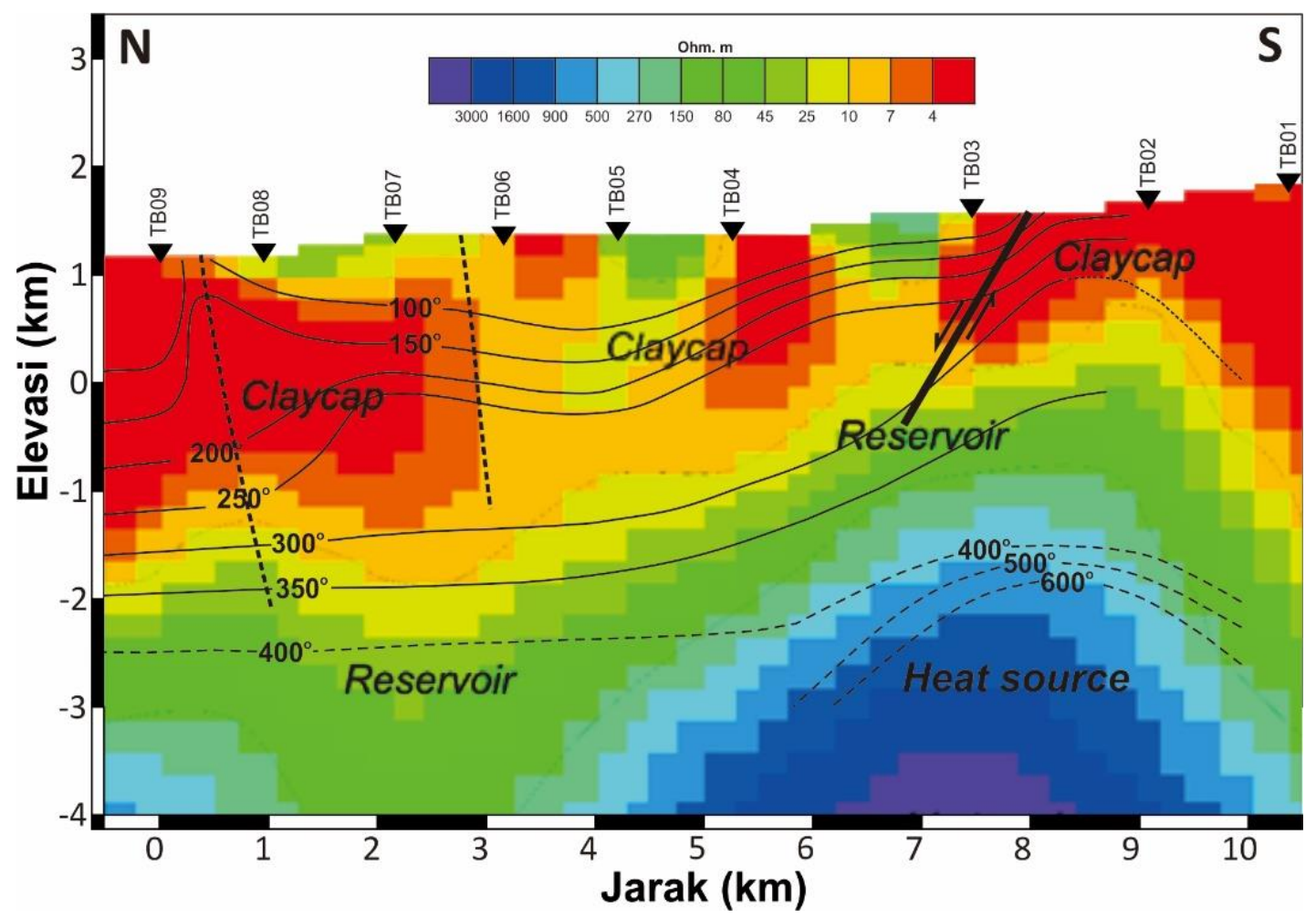

Gambar 8. Interpretasi penampang resistivitas bawah permukaan Karaha - Talaga Bodas hasil inversi 2D data MT dibandingkan dengan kontur isothermal dari Allis et al. (2000). Interpretasi keberadaan sesar normal di area selatan (garis hitam penuh) didukung oleh hasil analisis kontak vertikal, sementara dugaan sesar di area utara (garis hitam putus-putus) tidak meyakinkan. Segitiga hitam terbalik merepresentasikan lokasi stasiun pengukuran yang diproyeksikan dalam lintasan model inversi $2 \mathrm{D}$.

Penampang resistivitas 2D menunjukan nilai resistivitas yang dapat digolongkan ke dalam 3 (tiga) kelompok, yaitu resistivitas rendah, sedang, dan tinggi. Resistivitas rendah (1 - 10 Ohm.m) yang ditampilkan dengan warna merah sampai oranye, diduga berasosiasi dengan lapisan penudung pada sistem Panas Bumi. Resistivitas sedang (10 - 100 Ohm.m) ditampilkan dengan warna hijau, diduga berasosiasi dengan lapisan reservoir pada sistem Panas Bumi. Resistivitas tinggi (>100 Ohm.m) ditampilkan dengan warna ungu sampai biru, diduga berasosiasi dengan batuan sumber panas pada sistem Panas Bumi.

Dalam Gambar 8 terdapat hasil interpretasi dari model inversi 2D data MT daerah Karaha - Talaga Bodas. Secara garis besar model ini memperlihatkan tiga fitur utama. Fitur pertama merupakan batuan dengan nilai resistivitas tinggi, yang diinterpretasikan sebagai heat source. Fitur kedua adalah lapisan resistivitas menengah yang diinterpretasikan sebagai reservoir, dengan ketebalan 750 - 2000 meter. Fitur ketiga adalah lapisan resistivitas rendah yang diinterpretasikan sebagai clay cap pada bagian atas penampang. Nilai resistivitas menengah yang teramati pada bagian permukaan diinterpretasikan sebagai overburden yang tidak mengalami proses alterasi.

Bagian paling mencolok pada model inversi 2D adalah adanya tubuh bernilai resistivitas tinggi (ungu sampai biru) yang diduga sebagai batuan panas. Model konseptual (Allis et al., 2000) memperlihatkan keberadaan kuarsa diorit pada kedalaman kurang lebih 1500 meter di bawah permukaan laut. Hal itu selaras dengan penampang resistivitas 2D pada wilayah penelitian. Zona dengan nilai resistivitas tinggi (ungu sampai biru) yang diduga sebagai batuan panas diindikasikan sebagai intrusi diorit dan bersesuaian dengan batas atas kontur isothermal dari Allis et al., (2000). Zona ini berada pada bagian utara dan selatan wilayah penelitian. Namun pada intrusi di bagian utara, respon 
resistivitas tinggi baru ditemukan di kedalaman kurang lebih 3000 meter di bawah permukaan laut. Kedua tubuh intrusi tersebut selaras dengan hasil penelitian metode gaya berat yang sebelumnya telah dilakukan oleh (Tripp et al., 2002), yang menjelaskan bahwa terdapat dua closure di bagian utara dan selatan dari wilayah penelitian. Berdasarkan geometrinya yang terpisah sejauh lebih dari 5 kilometer, terdapat kemungkinan bahwa kedua tubuh intrusif ini merupakan dua sistem vulkanisme yang berbeda. Hal ini diperkuat oleh informasi Peta Geologi Lembar Tasikmalaya (Budhitrisna, 1986) yang mengindikasikan umur batuan yang berbeda (bagian utara berumur Plistosen, bagian selatan berumur Plistosen Akhir hingga Holosen)

Reservoir panasbumi diperkirakan berada pada kedalaman lebih dari 500 meter dari permukaan, dikenali dengan nilai resistivitas rendah hingga sedang (warna hijau) dengan geometri yang berundulasi, terutama di bagian utara. Reservoir panas bumi biasanya menunjukkan nilai resitivity yang lebih tinggi dari clay cap yang berada di atasnya (Ussher et al., 2000). Dalam penelitian ini, nilai resistivitas 20 sampai dengan 100 Ohm.m digunakan untuk mendeliniasi reservoir. Perbedaan nilai resistivitas antara clay cap dengan reservoir dapat dikaitkan dengan perbedaan derajat alterasi dari zona mineral smektit-zeolite pada clay cap menuju zona alterasi klorit-epidot (Hersir dan Bjornsson, 1991). Namun model inversi 2D yang dihasilkan tidak dapat membedakan antara reservoir karakter dominasi uap dan dominasi air.

Bagian dengan warna merah sampai oranye yang kemungkinan berkorelasi dengan lapisan penudung merupakan lapisan dengan nilai resistivitas rendah. Lapisan ini memiliki ketebalan kurang lebih 3000 meter di bagian utara dan menipis menjadi kurang lebih 1000 meter pada bagian selatan. Lapisan penudung paling tipis berada pada stasiun TB02 yang berada di sekitar Talaga Bodas. Hasil ini menunjukkan adanya perbedaan dengan hasil model inversi 1D dari (Raharjo et al., 2002), yang memperlihatkan lapisan clay cap menipis ke arah utara. Namun model inversi 2D kami memperlihatkan pola yang sama dengan kontur isotermal dari Allis et al., (2000) yang merupakan hasil dari korelasi data bor. Kontur isotermal $250^{\circ} \mathrm{C}$ terlihat semakin menurun ke arah utara. Hal ini dapat dikorelasikan dengan kondisi topografi dan keberadaan sumber panas yang membuat proses alterasi menjadi berbeda di bagian selatan dengan di bagian utara.

Pada lokasi di sekitar stasiun TB02 diduga terdapat rekahan yang menjadi jalur naik dari fluida panas ke permukaan. Berdasarkan peta manifestasi (Raharjo et al., 2002) ditemukan banyak manifestasi permukaan berupa fumarol dan mata air panas di sekitar TB02. Rekahan ini diduga kuat berkaitan dengan patahan yang berada diantara titik TB02 dan titik TB03. Hasil analisis ini sesuai dengan hasil analisis kontak vertikal yang menunjukan keberadaan kontak di antara titik TB02 dan titik TB03 yang diduga berupa patahan yang diinterpretasikan memiliki geometri kemiringan ke arah utara.

Berdasarkan informasi dari peta geologi lembar Tasikmalaya (Budhitrisna, 1986), terdapat beberapa buah kelurusan lain yang melewati lintasan MT kami, yaitu di sekitar TB09 dan di antara TB06 dan TB07. Pada penampang resistivitas $2 \mathrm{D}$ yang dihasilkan, teramati juga beberapa pola sebaran resistivitas yang patut dicurigai sebagai patahan, yaitu di antara TB09 dan TB08, serta di antara TB06 dan TB07. Kelurusan morfologi di permukaan mungkin berkolerasi dengan patahan di bawah permukaan, walaupun tidak selalu. Hasil analisis kontak vertikal memperlihatkan adanya kontak vertikal di sekitar TB03, namun tidak teramati pada dua lokasi lainnya (TB06-TB07 dan TB08-TB09). Oleh karena itu dugaan keberadaan sesar di sekitar TB03 digambarkan sebagai garis penuh, sedangkan TB06-TB07 dan TB08-TB09 digambarkan dengan garis putus-putus (tidak meyakinkan).

Menurut (Qahhar et al., 2015), zona upflow dapat ditandai dengan adanya dome batuan panas dan kelengkungan pada batuan konduktif diatasnya mengikuti bentuk dome batuan panas. Bentuk tersebut dapat terlihat seperti pada penampang resistivitas $2 \mathrm{D}$ yang dihasilkan dari model inversi. Dapat disimpulkan bahwa bagian selatan area penelitian (khususnya di sekitar stasiun TB02) merupakan zona upflow pada sistem panasbumi di lapangan ini.

Berdasarkan informasi geologi, penampang resistivitas 2D, analisis kontak vertikal, serta informasi dari peneltitian-penelitian sebelumnya (Allis et al., 2000; Raharjo et al., 2002; Tripp et al., 2002), model sistem panas bumi di lapangan Karaha - Talaga Bodas dapat diilustrasikan seperti 
pada Gambar 9. Warna biru muda merupakan overburden, warna biru pada gambar menunjukan clay cap, warna coklat muda menunjukan lapisan reservoir, warna magenta menunjukan heat source berupa intrusi diorit. Wilayah selatan penelitian diduga merupakan zona upflow dan wilayah utara diduga merupakan zona outflow.

Data yang digunakan dalam pemodelan ini memiliki beberapa keterbatasan jika dibandingkan dengan data yang digunakan oleh (Raharjo et al., 2002). Salah satunya adalah bahwa data pada pemodelan ini tidak melewati proses koreksi static shift. Fenomena static shift adalah bergesernya kurva pengukuran MT dalam sumbu vertikal (naik atau turun) yang mungkin terjadi pada pengukuran MT di lokasi dengan topografi ekstrim dan pada kasus inhomogenitas lateral dekat permukaan (Andrieux dan Wightman, 1984; Vozoff, 1991).

Sejumlah teknik telah coba dikembangkan untuk mengatasi static shift, koreksi menggunakan data time domain electromagnetic (TDEM) adalah metode yang paling banyak digunakan dalam eksplorasi panasbumi (Pellerin dan Hohmann, 1990; Sternberg et al., 1985). Namun terkadang teknik koreksi statik menggunakan data TDEM tidak dapat dilakukan (Stark et al., 2013). Selain itu pengukuran TDEM pada topografi yang ekstrim juga ternyata masih terpengaruh static shift (Watts et al., 2013).

Selain itu data dalam pemodelan ini hanya berjumlah 9 stasiun, sangat jauh berbeda dengan 180 stasiun data tersedia yang dibahas dalam Raharjo et al., (2002). Dengan jumlah stasiun pengukuran yang terbatas dalam penelitian ini, sulit untuk memberikan gambaran geometri 3D sistem panasbumi lapangan Karaha - Talaga Bodas. Perbedaan paling mendasar antara model kami dengan model dalam Raharjo et al., (2002) adalah pada dimensi pemodelannya. Pendekatan yang dilakukan para penulis tersebut adalah dengan pemodelan ke depan (forward modelling) dan inversi dalam kerangka 1D. Inversi 1D MT cocok digunakan untuk mendelineasi kedalaman clay cap, namun tidak untuk variasi resistivitas yang lebih dalam (Cumming dan Mackie, 2010). Model inversi 2D kami mengkonfirmasi modelmodel bawah permukaan sebelumnya (Allis et al., 2000; Raharjo et al., 2002; Tripp et al., 2002).

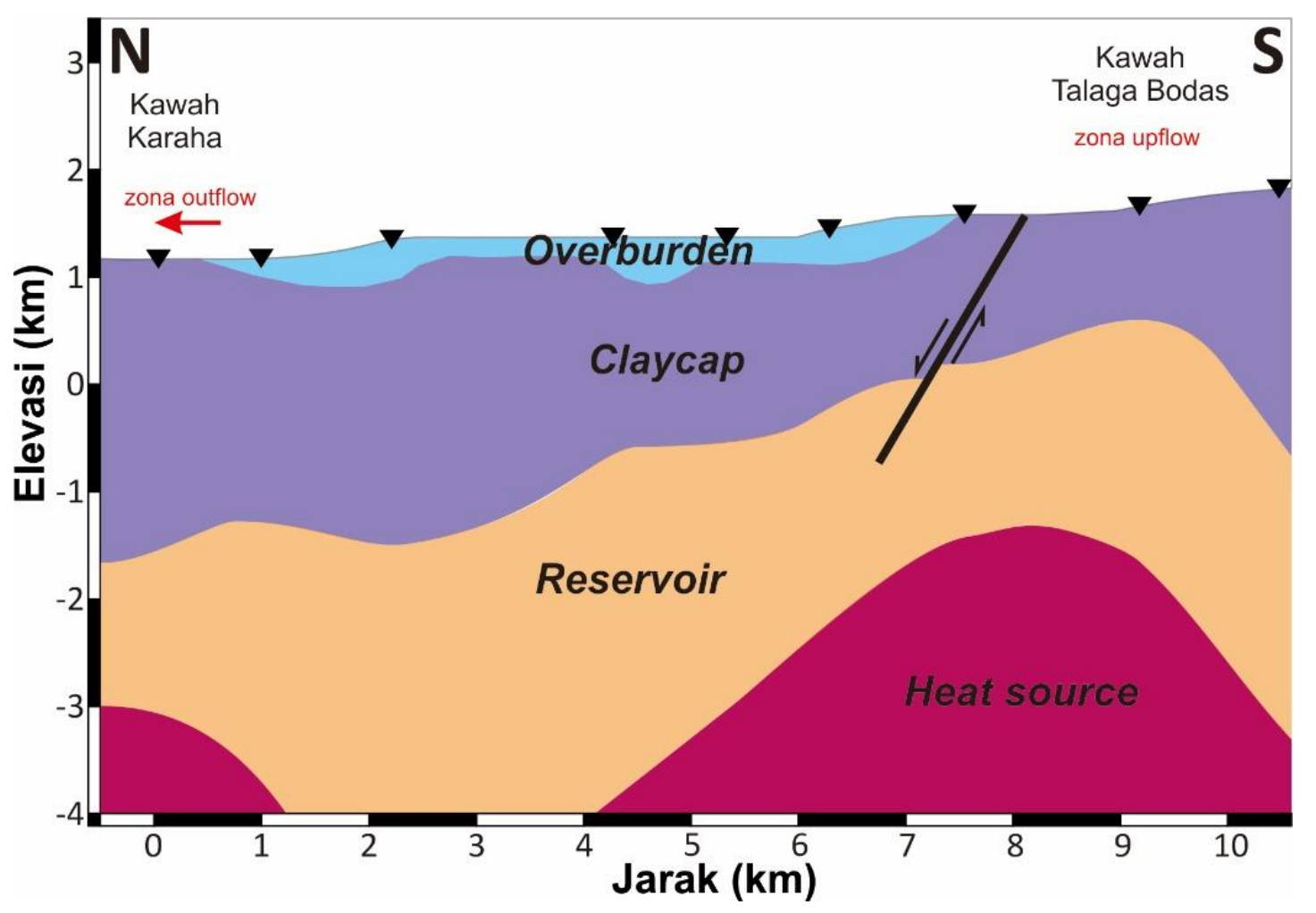

Gambar 9. Model sistem panas bumi lapangan Karaha-Talaga Bodas berdasarkan nilai resistivitas hasil model inversi 2D data MT. Bagian selatan daerah penelitian diinterpretasikan sebagai upflow, sedangkan bagian utara sebagai outflow. 


\section{KESIMPULAN}

Model resistivitas 2D pada daerah Panas Bumi Karaha-Talaga Bodas menunjukkan bahwa daerah penelitian memiliki 3 kelompok nilai resistivitas, yaitu resistivitas rendah, sedang, dan tinggi. Resistivitas rendah 1 sampai dengan 10 Ohm.m diduga berasosiasi dengan lapisan penudung dengan kedalaman berkisar 0 sampai $2.000 \mathrm{~m}$ dibawah permukaan laut. Resistivitas sedang 10 sampai dengan 100 Ohm.m diduga berasosiasi dengan lapisan reservoir dengan kedalaman berkisar antara $2.000 \mathrm{~m}$ sampai $4.000 \mathrm{~m}$ dibawah permukaan laut. Resistivitas tinggi lebih besar dari 100 Ohm.m yang diduga berasosiasi dengan batuan panas dengan kedalaman lebih dari 1.500 $\mathrm{m}$ dibawah permukaan laut pada zona Talaga, lebih dari 3.000 m pada zona Karaha, dan lebih dari $4.000 \mathrm{~m}$ pada zona di antara zona Talaga dan zona Karaha.

\section{UCAPAN TERIMA KASIH}

Data yang digunakan dalam penelitian ini berasal dari kegiatan Pusat Penelitian Geoteknologi, Lembaga Ilmu Pengetahuan Indonesia, dengan pendanaan DIPA tahun 2016. Penelitian ini tidak mungkin berjalan dengan baik tanpa bantuan Sunardi, Suyatno, Nyanjang, Sutarman, dan Dede Rusmana dalam proses pemerolehan data lapangan. Terima kasih kepada Lina Handayani atas diskusi-diskusi yang sangat bermanfaat selama pengerjaan penelitian ini. Ucapan terima kasih juga ditujukan kepada para editor dan reviewer yang telah banyak membantu dalam perbaikan naskah ini.

\section{DAFTAR PUSTAKA}

Allis, R., dan Moore, J. N., 2000. Evolution of Volcano-Hosted Vapor-Dominated Geothermal Systems. Geothermal Resources Council Transactions, 211-216.

Allis, R., Moore, J. N., Mcculloch, J., Petty, S., dan Derocher, T., 2000. Karaha-Telaga Bodas, Indonesia: A Partially VaporDominated Geothermal System. Geothermal Resources Council Transactions, $217-222$.

Andrieux, P., dan Wightman, W. E., 1984. The socalled static corrections in magnetotelluric measurements. Proceedings 54th Annual International Meeting, SEG, Abstracts. 4344.
BPS, 2017. Statistik Indonesia 2017, Jakarta: Badan Pusat Statistik.

Bronto, S., 1989. Volcanic geology of Galunggung, West Java, Indonesia. University of Canterbury.

Budhitrisna, T., 1986. Peta Geologi Lembar Tasikmalaya, Pusat Survei Geologi.

Cumming, W., dan Mackie, R., 2010. Resistivity Imaging of Geothermal Resources Using 1D , 2D and 3D MT Inversion and TDEM Static Shift Correction Illustrated by a Glass Mountain Case History. Proceedings World Geothermal Congress (April), 1-10.

Fauzi, A., Permana, H., dan Indarto, S., 2015. Regional Structure Control on Geothermal Systems in West Java, Indonesia, World Geothermal Congress, 19-25.

Garcia, X., dan Jones, A. G., 2002. Atmospheric sources for audio-magnetotelluric (AMT) sounding. Geophysics 67(2), 448-458. DOI:10.1190/1.1468604.

Geosystem, 2008. WinGLink: A guide, Milan.

Hansen, P. C., 1992. Analysis of discrete ill-posed problems by means of the L-Curve. SIAM Journal on Scientific Computing 34(4), 561-580. DOI:10.1137/1034115.

Hersir, G. P., dan Bjornsson, A., 1991. Geophysical exploration for geothermal resources: principles and application, Reykjavik: UNU Geothermal Training Programme.

Jones, A. G., dan Groom, R. W., 1993. Strikeangle determination from the magnetotelluric impedance tensor in the presence of noise and local distortion: rotate at your peril! Geophysical Journal International 113(2), 524-534. DOI:10.1111/j.1365-

246X.1993.tb00905.x.

Maryanto, S., Dewi, C. N., Syahra, V., Rachmansyah, A., Foster, J., Nadhir, A., dan Santoso, D. R., 2017. MagnetotelluricGeochemistry Investigations of Blawan Geothermal Field, East Java, Indonesia. Geosciences 7(2), 41. DOI:10.3390/geosciences7020041. 
Moore, J. N., Allis, R., Renner, J. L., Mildenhall, D., dan McCulloch, J., 2002. Petrologic Evidence for Boiling To Dryness in the Karaha-Telaga Bodas Geothermal System, Indonesia. Twenty-SeventhWorkshop on Geothermal Reservoir Engineering, 98108.

Nemčok, M., McCulloch, J., Nash, G., dan Moore, J., 2001. Fault Kinematics in the KarahaTelaga Bodas, Indonesia, Geothermal Field_An Interpretation Tool for Remote Sensing Data. In Geothermal Resources Council Transactions, 765-770.

Nemčok, M., Moore, J. N., Christensen, C., Allis, R., Powell, T., Murray, B., dan Nash, G., 2007. Controls on the Karaha-Telaga Bodas geothermal reservoir, Indonesia. Geothermics 36(1), 9-46. DOI:10.1016/j.geothermics.2006.09.005.

Parkinson, W. D., 1959. Directions of Rapid Geomagnetic Fluctuations. Geophysical Journal Of The Royal Astronomical Society 2(1), 1-14. DOI: $10.1111 / \mathrm{j} .1365-$ 246X.1959.tb05776.x.

Pellerin, L., dan Hohmann, G. W., 1990. Transient electromagnetic inversion: A remedy for magnetotelluric static shifts. Geophysics 55(9), 1242-1250. DOI: 10.1190/1.14429 40.

PhoenixGeophysics, 2005. Data Processing User Guide.

Powell, T., Moore, J., DeRocher, T., dan McCulloch, J., 2001. Reservoir Geochemistry of the Karaha - Telaga Bodas Prospect, Indonesia. Geothermal Resources Council Transactions, 363-367.

Qahhar, M. R. A., Daud, Y., Pratama, S. A., Zarkasyi, A., Sugiyanto, A., dan Suhanto, E., 2015. Modeling of Geothermal Reservoir in Lawu field Using 2-D Inversion of Magnetotelluric Data. Proceedings Indonesia Geathermal Convention \& Exhibition. Jakarta, 1-5.

Raharjo, I. B., Allis, R. G., dan Chapman, D. S., 2016. Geothermics Volcano-hosted vapordominated geothermal systems in permeability space. Geothermics 62, 22-32. DOI: 10.1016/j.geothermics. 2016.02.005.
Raharjo, I. B., Wannamaker, P., Allis, R., dan Chapman, D., 2002. Magnetotelluric interpretation of the Karaha Bodas geothermal field Indonesia. Proceeding Twenty-Seventh Workshop on Geothermal Reservoir Engineering Stanford University. Stanford: Stanford Geothermal Program.

Rodi, W., dan Mackie, R. L., 2001. Nonlinear conjugate gradients algorithm for 2-D magnetotelluric inversion. Geophysics 66 (1), 174 - 187. DOI:10.1190/ 1.1444893.

RUPTL-PLN, 2017. Rencana Usaha Penyediaan Tenaga Listrik PT. PLN Tahun 2017-2026, Jakarta.

Saputra, R. M., dan Widodo, 2017. Synthetic Modeling of A Geothermal System Using Audio-magnetotelluric (AMT) and Magnetotelluric (MT). Southeast Asian Conference on Geophysics. IOP Conf. Series: Earth and Environmental Science. IOP Conference Series: Earth and Environmental Science. DOI: 10.1088/ 1755-1315/62/1/012036.

Simpson, F., dan Bahr, K., 2005. Practical Magnetotellurics, Cambridge, Cambridge University Press. DOI: 10.1017/CBO9780 511614095.

Singarimbun, A., Gaffar, E. Z., dan Tofani, P., 2017. Modeling of Reservoir Structure by Using Magnetotelluric Method in the Area of Mt. Argopuro, East Java, Indonesia. Journal of Engineering and Technological Sciences 49(6), 833. DOI:10.5614/j.eng. technol.sci.2017.49.6.9.

Stark, M. A, Soyer, W., Hallinan, S., dan Watts, M. D., 2013. Distortion Effects on Magnetotelluric Sounding Data Investigated by 3D Modeling of HighResolution Topography. GRC Transactions 37.

Statistik-EBTKE, 2016. Statistik EBTKE 2016, Jakarta.

Statistik-Ketenagalistrikan, 2016. Statistik Ketenagalistrikan 2016 30th ed., Jakarta: Direktorat Jenderal Ketenagalistrikan KESDM RI.

Sternberg, B. K., Washburne, J. C., dan Pellerin, L., 1985. Correction for the static shift in 
magnetotellurics using transient electromagnetic soundings. Geophysics 53(11), 1459-1468. DOI:10.1190/ 1.14424 26.

Sudradjat, A., dan Tilling, R., 1984. Volcanic Hazards in Indonesia The 1982-83 Eruption of Galunggung. Episodes 7(2), 19.

Swift, C. M., 1967. A Magnetotelluric Investigation of an Electrical Conductivity Anomaly in the Southwestern United States. Massachusetts Institute of Technology.

Tripp, A., Moore, J., Ussher, G., dan McCulloch, J., 2002. Gravity Modeling of the Karaha Telaga Bodas Geothermal System, Indonesia. Procedings, Twenty-seventh Workshop on Geothermal Reservoir Engineering Stanford University. Stanford: Stanford Geothermal Program.

Ussher, G., Harvey, C., Johnstone, R., dan Anderson, E., 2000. Understanding the resistivities observed in geothermal systems. Proceedings World Geothermal Congress. Kyushu, 1915-1920
Vozoff, K., 1991. 8. The Magnetotelluric Method. In Electromagnetic Methods in Applied Geophysics. Investigations in Geophysics. Society of Exploration Geophysicists. DOI:10.1190/ 1.9781560802686.ch8.

Watts, M. D., Mackie, R., Scholl, C., dan Hallinan, S., 2013. Limitations of MT static shift corrections using time-domain EM data. SEG Technical Program Expanded Abstracts, 681-684. DOI:10.1190/segam2013-1078.1.

Wiese, H., 1962. Geomagnetische Tiefentellurik Teil II: Die Streichrichting der Undergrundstrukturn des Elektrischen Widerstandes, Erschlossen Aus Geomagnetischen Variationen. Geofisica pura e applicata 52(1), 83-103. DOI :10. 1007/BF01996002.

Zhang, L., Hao, T., Xiao, Q., Wang, J., Zhou, L., Qi, M., Cui, X., dan Cai, N., 2015. Magnetotelluric investigation of the geothermal anomaly in Hailin, Mudanjiang, Northeastern China. Journal of Applied Geophysics 118, 47-65. 